\title{
IMPROVING TRIBOLOGICAL BEHAVIOUR IN THE CASE OF A NON-CONVENTIONAL TREATED STEEL FOR INDUSTRIAL GEARINGS
}

\author{
Carmen-Penelopi PAPADATU1 \\ ${ }^{1}$ Dunarea de Jos University of Galati, Faculty of Engineering, Mechanical Engineering Department, \\ Romania, papadatu.carmen@yahoo.com
}

https://doi.org/10.37904/metal.2021.4195

\begin{abstract}
A thermo-magnetic treatment applied before plasma nitriding modifies the characteristics of the mechanical resistance of the steel, the hardness and the resistance of the material during corrosion process. A nonconventional treatment applied to steel for industrial gearings have been studied in this paper. It have been demonstrated that the energy of the magnetic field conduct to the mechanical oscillations of micro-areas in material and intervenes in the balance of the global power of the phase transformations in solid state changing the thermodynamics, kinetics and the mechanisms of the processes, the microstructures and properties of the steel. The wear tests (dry friction) have been realized using an Amsler stand. The plasma nitriding plant used was the INI 150 which was made by the Institute of Radiation Physics and Technology in collaboration with the "Electrotechnics" Enterprise and the Nuclear Apparatus from Romania, used for industrial nitriding of small pieces. INI 150 was based on the physical phenomenon of a double cathode at plasma (ion) nitriding. This work is a review of my researches from the last years.
\end{abstract}

Keywords: Steel, properties, thermo-magnetic treatment, plasma nitriding, wear tests

\section{INTRODUCTION}

The structural aspects into superficial layer of the steel are studied during friction process by using of an Amsler machine, taking two sliding degrees, different contact pressures, and testing time. By X-ray diffractometry the changes regarding the austenite residual, $\mathrm{IFe}_{4} \mathrm{~N}$ and the degree of thetragonality of martensite during friction process are carried out. $\mathrm{Fe}_{4} \mathrm{~N}$ phase being a "hard" phase, increasing the amount of this phase in the thermochemically treated surface layer involves the increasing of the hardness and wear resistance of the surface layer [1,2]. The loss of mass, the intensity of the wear (dry friction) and micro-hardness in the superficial layer at different stage of friction have been monitored. The performed tests allowed establishing the influence of the thermal, magnetic and mechanical parameters on behaviour of the steel taking in study during friction process $[3,4]$.

The properties of the nitrided layer depend on the nature of the nitride phases. As the nitriding temperature increases, the nitriding duration decreases, but the hardness of the nitrided layer decreases due to the coalescence of the nitrides of the alloying elements. It should be noted that the $\mathrm{Fe} 2 \mathrm{~N}(\xi)$ phase - which has a rhombic structure (deformed structure of the $\varepsilon$ phase) and a low hardness, does not appear in the structure of the researched steels. Within the accuracy limits of the DRON3 diffractometer, the existence of this phase was not highlighted $[1,5]$.

\section{EXPERIMENTAL PROCEDURE AND RESULTS}

The samples have been realized as rollers from a steel grade for improvement treatment for machine parts construction with the following principal content: $0.42 \% \mathrm{C}, 0.02 \% \mathrm{Al}, 1.02 \% \mathrm{Cr}, 0.68 \% \mathrm{Mn}, 0.17 \% \mathrm{Mo}$, 
$0.33 \% \mathrm{Si}, 0.26 \% \mathrm{Ni}, 0.22 \% \mathrm{Cu}, 0.030 \% \mathrm{P}, 0.026 \% \mathrm{~S}$. Molybdenum content exists in the composition of the steel and this chemical element decreases the stiffening phenomenon.

The first part from the complex experimental program consisted of thermo-magnetic treatments. The treatment $\mathrm{t} 1$ represents a hardening treatment $\left(\right.$ at $850^{\circ} \mathrm{C}$ ) followed by a high tempering (at $580^{\circ} \mathrm{C}$ ), being a classic improvement treatment. The treatment $\mathrm{t} 2$ represents a complete martensitic hardening process in weak alternative magnetic field (with cooling in water) and high tempering treatment (with cooling in water, in strong magnetic field - Alternative Current (A.C.). In this case, the samples have been introduced in the centre of the electrical coil located in the walls of a cylindrical oven [2]. The treatment $t 3$ represents a thermo-magnetic treatment corresponding to the treatment with cooling in water in magnetic field- Alternative Current (A.C.). After thermo-magnetic treatments, a thermochemical treatment as plasma nitriding at $530{ }^{\circ} \mathrm{C}$ have been applied. The final treatments have been noted: $\mathrm{T} 1=\mathrm{t} 1$ followed by plasma nitriding at $530{ }^{\circ} \mathrm{C}(8 \mathrm{~h}$, duration depends on the dimensions of the samples); $\mathrm{T} 2=\mathrm{t} 2$ followed by plasma nitriding at $530^{\circ} \mathrm{C}$, and $\mathrm{T} 3=\mathrm{t} 3$ followed by plasma nitriding at $530{ }^{\circ} \mathrm{C}$.

In Table 1 have been presented the micro-hardness values $\mu \mathrm{Hv}_{0.1}$ obtained after thermo-magnetic treatment, comparing with the results obtained through the classic treatment. Mass loss $(\Delta \mathrm{m})$ and the intensity of the wear $\left(\mathrm{l}_{\mathrm{u}}\right)$ have been presented too. There are considered samples different treated. Distance from the superficial layer until the experimental trace was measured and the value was $0.05 \mathrm{~mm}$. In this point, the Vickers micro-hardness had the values introduced in the following table:

Table 1 Results corresponding to classic treatment ( $\mathrm{T} 1)$ and non-conventional treatments (T2 and T3)

\begin{tabular}{|c|c|c|c|c|c|c|c|c|c|}
\hline $\begin{array}{l}\text { Treatment } \\
\text { Code }\end{array}$ & $\begin{array}{c}\text { Normal } \\
\text { Load Q } \\
\text { [daN] }\end{array}$ & $\begin{array}{c}\begin{array}{c}\text { Sliding } \\
\text { degrees }\end{array} \\
\xi[\%]\end{array}$ & $\begin{array}{c}\text { Mass } \\
\text { loss } \\
\Delta \mathrm{m} \\
(\mathrm{dm}) \\
{[\mathrm{g}]}\end{array}$ & $\begin{array}{l}\text { The depth } \\
\text { of the } \\
\text { weared } \\
\text { layer } \\
\text { Uh' [mm] }\end{array}$ & $\begin{array}{c}\text { The } \\
\text { intensity } \\
\text { of the } \\
\text { wear } \\
\text { lu' }\end{array}$ & $\begin{array}{l}\Delta \mathrm{t} \\
{[\mathrm{h}]}\end{array}$ & $\begin{array}{c}\mu \\
\text { (Friction } \\
\text { coeffi } \\
\text { cient) }\end{array}$ & $\begin{array}{c}\mathbf{I} \\
\mathrm{Fe}_{4} \mathbf{N} \\
\sim \%\end{array}$ & $\begin{array}{c}\mu H V_{0.1} \\
{\left[\mathrm{daN} / \mathrm{mm}^{2}\right]}\end{array}$ \\
\hline $\begin{array}{c}\mathrm{T}_{1} \\
\text { (Classic) }\end{array}$ & \multirow[t]{2}{*}{75} & \multirow{4}{*}{10} & $\begin{array}{l}- \\
0.025 \\
0.035 \\
0.030 \\
\end{array}$ & 0.100 & $\begin{array}{l}- \\
5.89 \\
4.42 \\
4.42 \\
\end{array}$ & $\begin{array}{l}0 \\
1 \\
2 \\
3 \\
\end{array}$ & 0.133 & $\begin{array}{l}18 \\
22 \\
14 \\
19 \\
\end{array}$ & 1159 \\
\hline $\mathrm{T}_{2}$ & & & $\begin{array}{l}-\overline{-} \\
0.020 \\
0.020 \\
0.025\end{array}$ & 0.070 & $\begin{array}{l}- \\
2.95 \\
1.47 \\
1.47 \\
\end{array}$ & $\begin{array}{l}0 \\
1 \\
2 \\
3 \\
\end{array}$ & 0.133 & $\begin{array}{l}14 \\
22 \\
22 \\
15 \\
\end{array}$ & 1513.8 \\
\hline $\mathrm{T}_{1}$ & \multirow{4}{*}{150} & & $\begin{array}{l}- \\
0.035 \\
0.040 \\
0.040 \\
\end{array}$ & 0.120 & $\begin{array}{l}- \\
5.89 \\
5.89 \\
5.89 \\
\end{array}$ & $\begin{array}{l}0 \\
1 \\
2 \\
3 \\
\end{array}$ & 0.116 & $\begin{array}{l}23 \\
25 \\
19 \\
37 \\
\end{array}$ & 1159 \\
\hline $\mathrm{T}_{2}$ & & & $\begin{array}{l}- \\
0.035 \\
0.025 \\
0.030\end{array}$ & 0.090 & $\begin{array}{l}- \\
4.42 \\
4.42 \\
4.42\end{array}$ & $\begin{array}{l}0 \\
1 \\
2 \\
3\end{array}$ & 0.116 & $\begin{array}{l}14 \\
14 \\
15 \\
16\end{array}$ & 1513.8 \\
\hline $\mathrm{T}_{\mathrm{CA}}\left(\mathrm{T}_{3}\right)$ & & 20 & $\begin{array}{c}- \\
0.030 \\
0.030 \\
0.025\end{array}$ & 0.095 & $\begin{array}{r}- \\
4.42 \\
3.68 \\
3.68 \\
\end{array}$ & $\begin{array}{l}0 \\
1 \\
2 \\
3\end{array}$ & 0.121 & $\begin{array}{l}24 \\
36 \\
38 \\
36\end{array}$ & 1354.5 \\
\hline $\begin{array}{c}\mathrm{T}_{1} \\
\text { (Classic) }\end{array}$ & & 20 & $\begin{array}{l}0 . \\
0.040 \\
0.055 \\
0.050 \\
\end{array}$ & 0.135 & $\begin{array}{r}- \\
5.89 \\
6.70 \\
6.70 \\
\end{array}$ & $\begin{array}{l}0 \\
1 \\
2 \\
3 \\
\end{array}$ & 0.121 & $\begin{array}{l}17 \\
14 \\
19 \\
26 \\
\end{array}$ & 1159 \\
\hline
\end{tabular}

The wear tests have been made on Amsler machine, type roller on roller, with different diameters to obtain different sliding degrees (for example, for $\xi=20 \%$, the outer diameter of the conducting roller had $43.9 \mathrm{~mm}$ and the second roller had $40 \mathrm{~mm}$. Rollers width was $10 \mathrm{~mm}$. The wear moment $\mathrm{Mf}=40 \mathrm{daN} \cdot \mathrm{cm}$, the normal 
load $(Q)$ was 150 daN, the friction coefficient $(\mu)$ was 0.121 , the lenght of friction zone of the rollers (Lf) was $74.606 \mathrm{~m})$.

In Figure 1 have been presented the mass loss (dm1" and dm2") corresponding to the treatment T1 and T2, for a normal load $Q=75$ daN and a sliding degrees $\xi=10 \%$.

In Figure 2 have been presented the mass loss ( $\mathrm{dm} 1$ ' and dm2') corresponding to the treatment T1 and T2, for a normal load $Q=150$ daN and a sliding degrees $\xi=10 \%$.

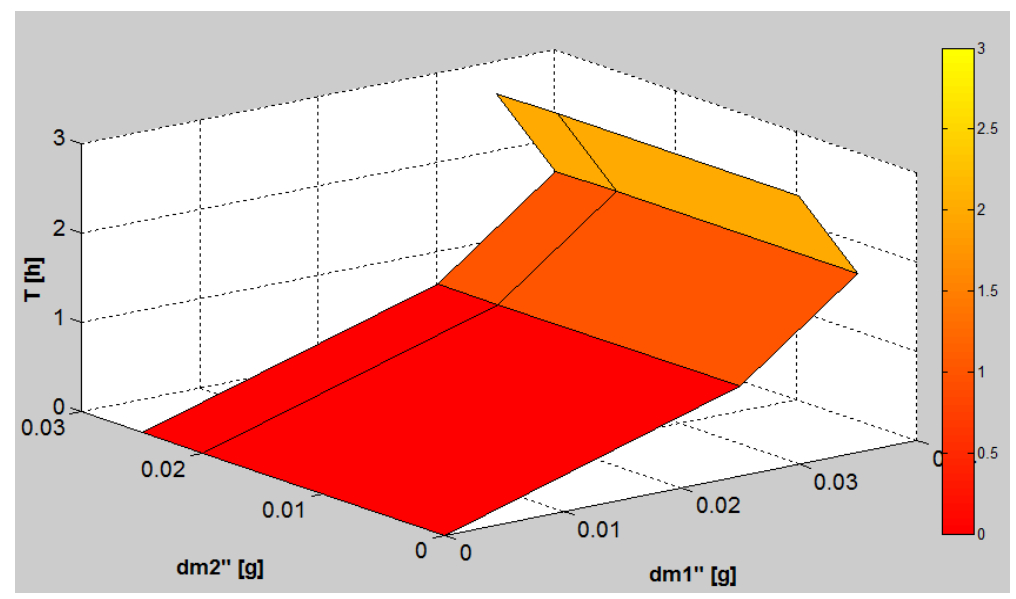

Figure 1 Mass loss during wear tests, for T1 and T2, Q=75 daN, (10\%)

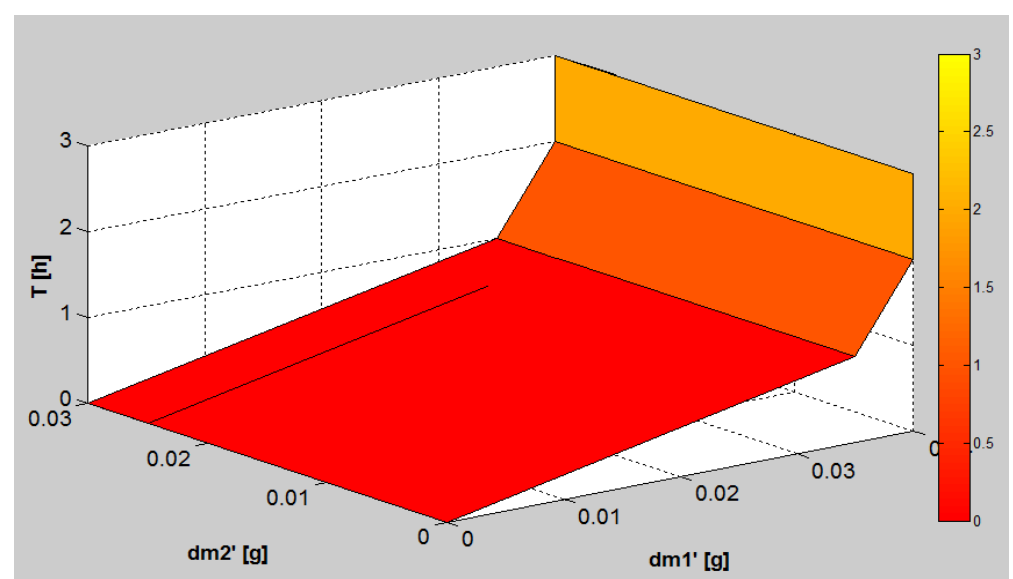

Figure 2 Mass loss during wear tests, for $\mathrm{T} 1$ and $\mathrm{T} 2, \mathrm{Q}=150$ daN, (10\%)

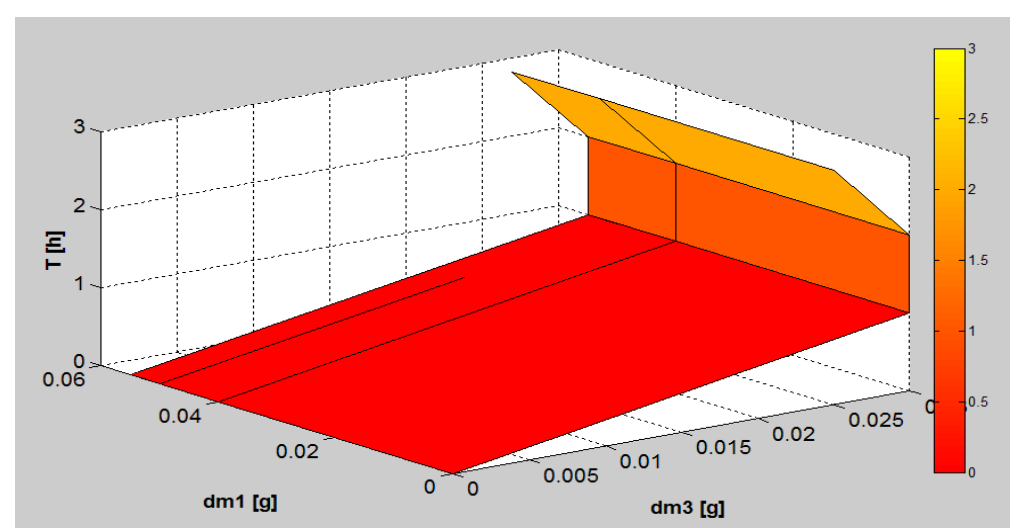

Figure 3 Mass loss during wear tests, for $\mathrm{T}_{1}$ and $\mathrm{T}_{\mathrm{CA}}, \mathrm{Q}=150$ daN, (20\%) 
In Figure 3 have been presented the mass loss $(\mathrm{dm} 1$ and $\mathrm{dm} 2)$ corresponding to the treatment $\mathrm{T} 1$ and $\mathrm{T}_{\mathrm{CA}}$ (A.C.), for a normal load $\mathrm{Q}=150 \mathrm{daN}$ and a sliding degrees $\xi=20 \%$.

In Figure 4, the Intensities of the wear (lu1', lu2') corresponding to the treatment T1 and T2, for a normal load $\mathrm{Q}=75 \mathrm{daN}$ and a sliding degrees $\xi=10 \%$, have been presented.

In Figure 5, the Intensities of the wear (lu1, lu2) corresponding to the treatment T1 and to the treatment T2, for a normal load $Q=150$ daN and a sliding degrees $\xi=10 \%$, have been presented.

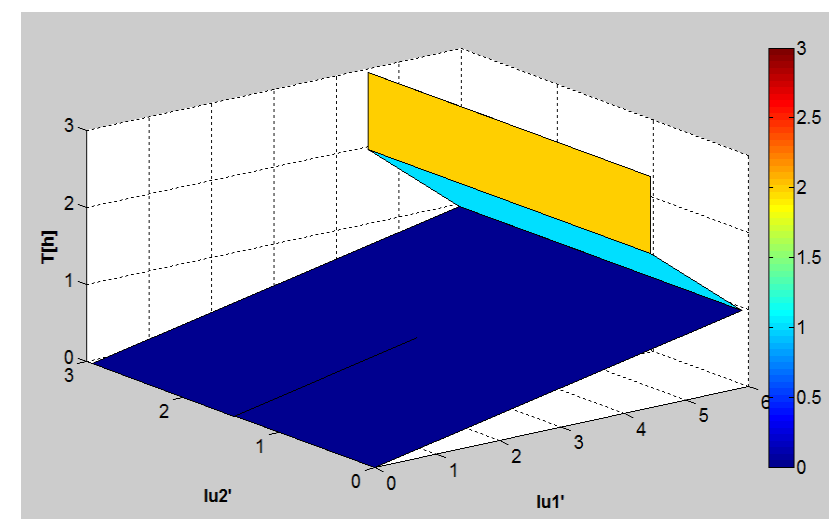

Figure 4 The Intensity of the wear (lu1', lu2') corresponding to the treatment $\mathrm{T} 1$ and $\mathrm{T} 2$, for a normal load $Q=75 \mathrm{daN}(\xi=10 \%)$.

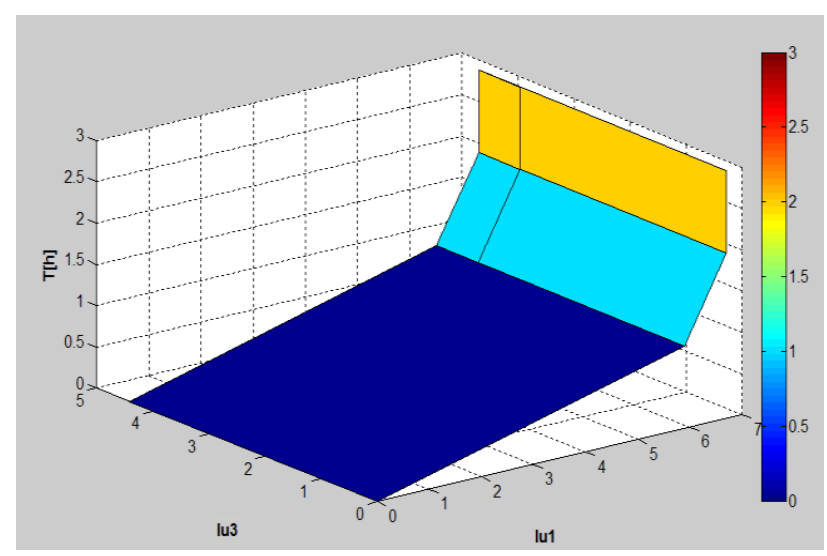

Figure 6 Intensity of the wear (lu') corresponding to the treatment $\mathrm{T} 1$ and $\mathrm{T}_{\mathrm{CA}}$, for $\mathrm{Q}=150 \mathrm{daN}$,

$$
\xi=20 \% \text {. }
$$

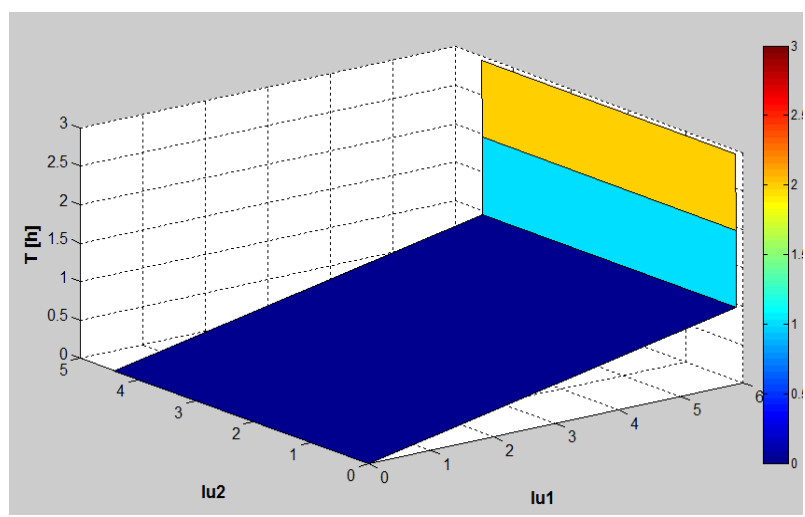

Figure 5 The Intensity of the wear (lu1, lu2) corresponding to the treatment $\mathrm{T} 1$ and $\mathrm{T} 2$, for a normal load $Q=150$ daN $(\xi=10 \%)$.

The amount of $\mathrm{Fe}_{4} \mathrm{~N}$ phase has a maximum in the case of applying the T3 treatment both before the wear process and after the friction wear tests (see Table 1). This situation can be explained by the fact that, $\mathrm{Fe}_{4} \mathrm{~N}$ being a harder phase, it "stays" in the composition of the surface layer longer in the process of frictional wear. The intensity of the wear due to appreciates the depth of the worn layer, in different cases of the treatments. Because of that, the depth of the worn layer by dry friction had been found in the case of the non-conventional treatments T2 and T3. Hence, the depth of the worn layers is smaller in the case of nonconventional treatment comparing to classic treatment $\mathrm{T} 1$.

In Figure 6 have been presented the Intensity of the wear corresponding to the treatment $\mathrm{T} 1$ and to the treatment $T_{C A}$, for a normal load $Q=150$ daN and a sliding degrees $\xi=20 \%$.

In Figures 7, 8 and $\mathbf{9}$ the evolution of the phase $\mathrm{Fe}_{4} \mathrm{~N}$ have been presented, in three cases: on classic treatment case as landmark - taking in consideration the different values for the Normal Load $Q$ and sliding degrees $\xi$ - and considering non-conventional treatment cases T2 and T3. 


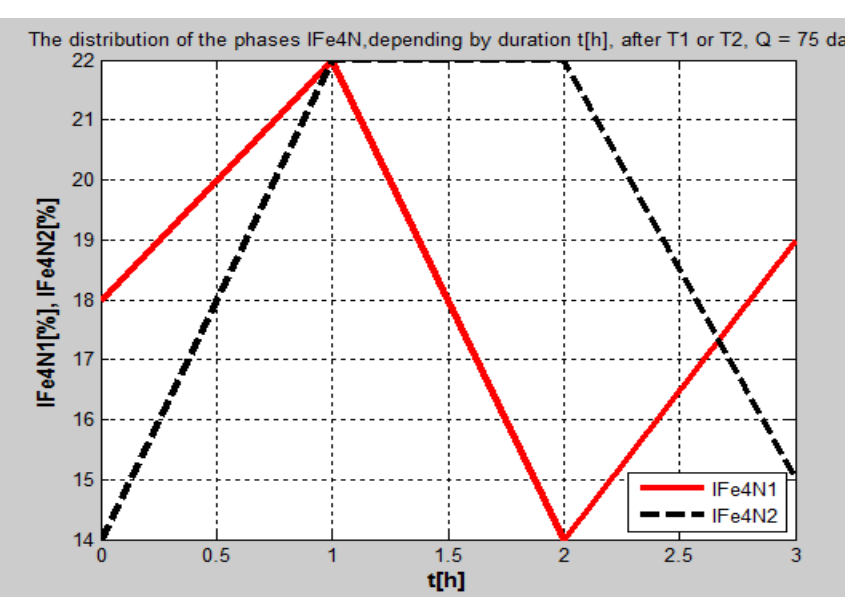

Figure 7 The distribution of the phase $\mathrm{IFe}_{4} \mathrm{~N}$, depending by duration $\mathrm{t}[\mathrm{h}]$, after T1 or T2 treatment, $\mathrm{Q}=75 \mathrm{daN}, \xi=10 \%$

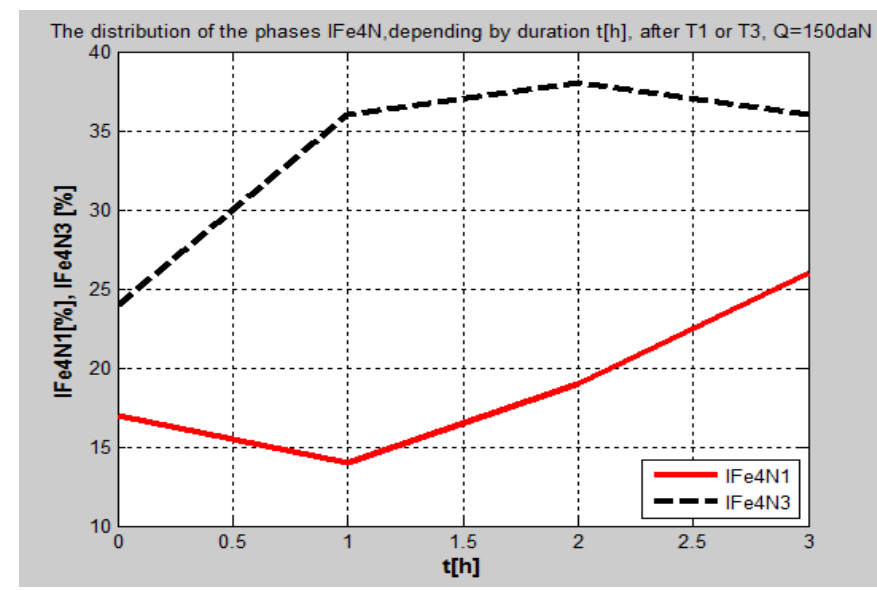

Figure 9 The distribution of the phase IFe4N depending by duration t[h], after T1 or T3 treatment, $Q=150 \mathrm{daN}, \xi=20 \%$

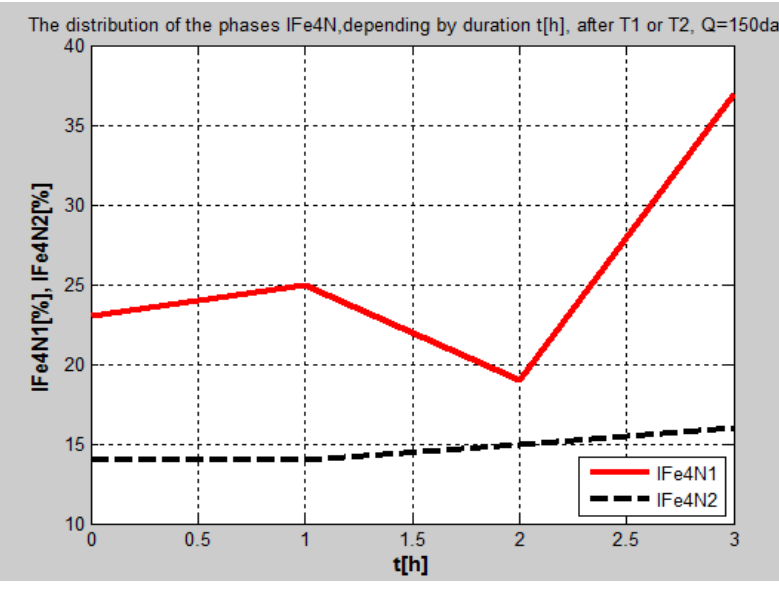

Figure 8 The distribution of the phase IFe4N depending by duration $\mathrm{t}[\mathrm{h}]$, after $\mathrm{T} 1$ or $\mathrm{T} 2$, $Q=150 \mathrm{daN}, \xi=10 \%$

In Figures 7 and $8, \mathrm{IFe}_{4} \mathrm{~N}$ corresponding to $\mathrm{T} 1$ treatment had a cyclical evolution and in the case of the non-conventional treatment, the evolution was ascending. In figure 9, upon frictional wear with the same Normal load $Q=150$ daN and at the same sliding degree of $20 \%$, an increase in the amount of $\mathrm{Fe}_{4} \mathrm{~N}$ was observed on the diffractograms.

The highest amount of $\mathrm{Fe}_{4} \mathrm{~N}$ phase is observed in the situation of applying the T3 treatment (the improvement treatment with cooling in magnetic field-alternating current A.C., $\mathrm{H}=1300 \mathrm{~A} / \mathrm{m}$, treatment followed by ionic nitriding at $530^{\circ} \mathrm{C}$ ). In microvolume, after thermomagnetic treatment, the amount of Martensite (M) increased very much.[2]

By the action of the magnetic field, the number of martensite germs increases in the same volume, resulting in a finer-finer martensite than in the conditions of classical heat treatment. Martensite increases the hardness of steel.Due to the internal magnetostrictive forces, the conditions for the diffusion of carbon atoms within the elementary cells are created. As a result, the degree of tetragonality of martensite decreases and the fragility of the material decreases.

Each of the phases of the magnetic field heat treatment influences the durability differently: the hardening in the magnetic field leads to a $49 \%$ increase in durability compared to the classic hardening. The return in the magnetic field determines an increase in durability of only $40 \%$ compared to the classic treatment.

At the low recovery of classical hardened steel, the magnetic field slows down the decomposition process of martensite (M), and if the steel has been hardened in magnetic field, the decomposition process of martensite is much slower, there is a tendency to increase the stability of martensite. At the same time, the magnetic field also influences the kinetics of the decomposition of the residual austenite by isotherm, on the heat treatment of tempering, but in the sense of accelerating the transformation. The main cause of these phenomena is the 
effect of magnetostriction that produces stresses in the microvolumes of the solid solution - stresses that interact with the elastic stress field of dislocations. Magnetostriction represents the dimensional variation of a ferromagnetic material under the action of a magnetic field also called the Joule effect, which depends on the size and direction of the outer magnetic field, the material and the heat treatment previously applied to this material.

\section{CONCLUSION}

Overlapping a magnetic field - alternative current - in special conditions, on the improvement treatment applied to steel before the plasma nitriding process, it was observed that the quantity of the $\mathrm{Fe}_{4} \mathrm{~N}$ phase increased in the plasma nitrided layer and the distribution of this phase during wear tests on Amsler stand and implies an increasing of the wear resistance and an improvement of the mechanical properties of the superficial layer of the steel. Also, after thermo-magnetic treatment applied initially, the hardness of the steel increased with $40 \%$ in the case of the non-conventional treatment T3 and the micro-hardness of the superficial layer of steel increased with approx. 20 - 30\% after thermo-magnetic treatment, depending on the treatment regime applied, comparing to the classic treatment applied. From the diffractometric point of view, the samples had changes of the content of $\mathrm{Fe}_{4} \mathrm{~N}$ phase in the superficial layer thermo-chemically treated. So, the magnetic field influences positively the mechanical properties of the steel.

\section{ACKNOWLEDGEMENTS}

This ideea started during the stage of my doctoral Thesis and the researches continued after the end of Doctoral program. The experimental program was made in Romania, the wear tests have been made at "Dunarea de Jos" University from Galati. Thermo-magnetic treatments have been made at Transilvania University Laboratory from Brasov, Romania.

\section{REFERENCES}

[1] GHEORGHIES, C. and STEFANESCU, I. Effects of Thermomagnetic Treatment on Microstructure and Mechanical Properties of Rolling Bearing Steel. Journal of Iron and Steel Research International. [online]. 2010, vol. 17, no. 9, pp.46-52. Available from: https://doi.org/10.1016/S1006-706X(10)60141-0.

[2] PAPADATU, C P. Possibilities to improve the quality of some steels used in the metallurgical industry. "Dunarea de Jos" University Publishing Foundation, Galati, Romania. ISBN: 978-973-627-371-1, 2006.

[3] PAPADATU, C. P., SANDU, A., BORDEI, M., SANDU, G. Study on the Influence of the Treatment in Magnetic Field on the Nitrided Layer in Plasma. Revista de Chimie. 2017, vol. 68, pp. 675- 679. WOS: 000400732400009.

[4] BALTES, L., FLOREA, R., MARKOS, Z. Influence of the thermo-magnetic treatments on the durability of drills from Rp5 steel. In: International Conference on Materials Science Proceeding BRAMAT. Brasov, 2001, p.325.

[5] MITTEMEIJER, E.J., Steel Heat Treating Fundamentals and Processes in J. Dossett, G.E. Totten (Eds.), ASM

[6] Handbook. Volume 4A, 2013. ISBN-13: 978-1-62708-011-8.

[7] ROLIŃSKI E, SHARP G, BRONDUM K and PETERSON N (2005a), 'P/M turbo charger and armature components: plasma nitriding and nitrocarburizing to reduce friction wear'. In: SAE World Congress, Detroit. Warrendale, PA: SAE International, 2005, paper 2005- 01-0722.

[8] PAPADATU, C.P. Experimental studies regarding wear processes through dry friction of the superficial layer for an unconventional treated steel. In: IOP Conference Series: Materials Science and Engineering. [online]. 2017, vol. 174, no. 01201. Available from: https://doi.org/10.1088/1757-899X/174/1/012014. 